\title{
North beltway of Cracow - selected elements of impact on the environment and the real estate market
}

\author{
Krzysztof Butryn ${ }^{1}$, Elżbieta Jasińska ${ }^{1}$, Oleksandra Kovalyshyn ${ }^{2}$, Edward Preweda ${ }^{1, *}$ \\ ${ }^{1}$ AGH University of Science and Technology, Poland \\ ${ }^{2}$ Lviv National Agrarian University, Lviv, Ukraine
}

\begin{abstract}
The construction of such a large road facility as the city beltway can not have an impact on the environment. In addition to the obvious benefits to transport, attention should be paid to the environment of the area, in particular noise and air pollution. In December 2017, the Minister of Infrastructure and Construction signed the investment program for the implementation of the northern Krakow bypass road. General Directorate for National Roads and Motorways, the Kraków branch has announced an open tender for its implementation into the EU. Today, in our tender for the design and construction of the northern bypass road of Krakow, 8 offers was received. All tenderers give the date of completion of all works within 47 months. The length of the two-lane section of the beltway is about $12 \mathrm{~km}$, each roadway will have 3 lanes. The POK (North Beltway od Cracow) will run mostly in the area of the Zielonki commune, through the towns of: Zielonki, Bibice, Węgrzce, Bosutów, Dziekanowice and Batowice. The analysis carried out show a very large increase in the value of real estates located in the northern part of Krakow and adjacent areas in recent years. According to the authors, the construction of the northern beltway and easier access to the center of Krakow through the modernization of the November 29 avenue will contribute to even greater interest in real estates located in this area. Real estate prices will certainly increase, rather only at the beginning of the investment. Residents will gain the comfort of an alternative transport line, but there will also be an increase in noise and air pollution, which is a particularly important problem in and around Krakow. The article presents the validation of these three issues in relation to changes in the real estate market in the commune of Zielonki.
\end{abstract}

\section{Introduction}

For the end of work on the Krakow beltway, drivers and residents of the metropolises and surrounding communities have been waiting for years. In the tender announced in December 2017 by the General Directorate for National Roads and Motorways, the most advantageous offer for the project and construction of the northern bypass was made by the Turkish-Polish consortium. The contractor declared that the investment would be completed in 47 months for the amount of nearly PLN 1.3 billion. Two consortia have appealed against the tender results, which will delay the process of selecting the contractor. It is optimistic that the contract may be signed in August 2018.

The project included three basic concepts of the bypass (Fig. 1).

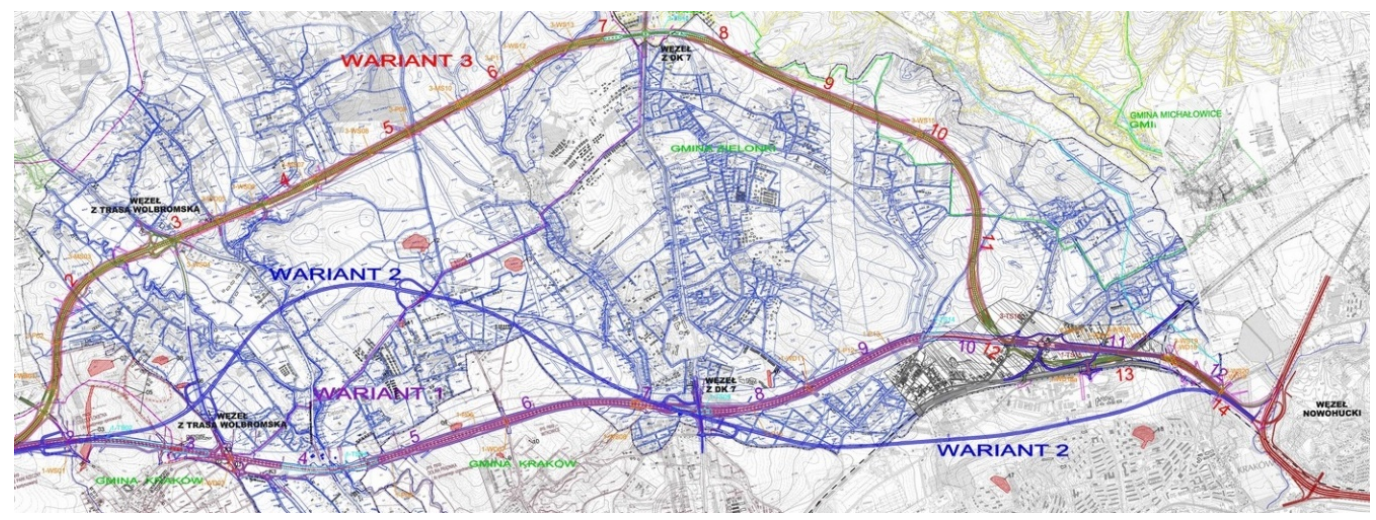

Fig. 1. Designed variants of the northern bypass of Krakow. Source [20]

* Corresponding author: preweda@agh.edu.pl 
Basic information on the necessity to buy land and make demolition of buildings in individual variants of the planned bypass is summarized in Tab. 1 .

Table 1 Area of land and buildings in square meters

\begin{tabular}{|c|c|c|c|c|}
\hline \multicolumn{2}{|c|}{ AREA } & variant 1 & variant 2 & variant 3 \\
\hline \multirow{3}{*}{$\begin{array}{l}\text { land } \\
\text { buyout }\end{array}$} & Urbanized & 165000 & 228070 & 105360 \\
\hline & $\begin{array}{c}\text { Medium } \\
\text { Urban }\end{array}$ & 282000 & 300150 & 252854 \\
\hline & Agricultulal & 294970 & 189300 & 447629 \\
\hline \multirow{3}{*}{$\begin{array}{l}\text { demoliti } \\
\text { on of } \\
\text { build- } \\
\text { ings }\end{array}$} & $\begin{array}{c}\text { High } \\
\text { standard }\end{array}$ & 1200 & 2320 & 845 \\
\hline & $\begin{array}{l}\text { Medium } \\
\text { standard }\end{array}$ & 300 & 440 & 400 \\
\hline & $\begin{array}{c}\text { Low } \\
\text { standard }\end{array}$ & 200 & 960 & 640 \\
\hline
\end{tabular}

In the area where the beltway is planned, average land purchase prices are at PLN 350/sqm in urbanized areas, PLN 250/sqm in medium-urbanized areas and around PLN 150/sqm for agricultural land. Land purchase, according to 3 route variants, would be in the range of 170-180 million PLN. Demolition costs are estimated at 15-30- 13 million PLN respectively (were 100 PLN is amout of 23 EURO).

The second variant was excluded in 2009 due primarily to the largest collision with the development of the Zielonki commune and the course in the immediate vicinity of the Mistrzejowice housing estate with a dense construction of multi-storey blocks. Variants 1 and 3, in accordance with the Act [16] were subjected to detailed analysis in terms of environmental impact.

\section{Characteristics Variants of The Bypass Route}

\subsection{Variant 1}

The starting point of variant 1 is the node in Modlniczka on the national road No. 94. The road passes through Fort Tonie and runs through agricultural areas to the node with the planned provincial road No. 794. Heading further east, the route crosses the boundaries of the commune of Zielonki and passes through undeveloped areas up to the suburb of Krakow. A tunnel is planned here, which will reduce the impact of the beltway on the surroundings. The northern bypass will cross several tunnels along this tunnel and the Prądnik Biały river (Fig. 2). Heading to the "Węgrzce" junction with the national road No. 7 , the planned route runs mainly through agricultural areas, including the Bibczanka stream. The route bypasses the village of Węgrzce and undeveloped areas, reaches the county road No. 2156K. Through the municipal road to Bosutowa the route runs through a tunnel, which allows you to bypass the buildings along the road to Bosutowa and Dziekanowice (Fig. 3).

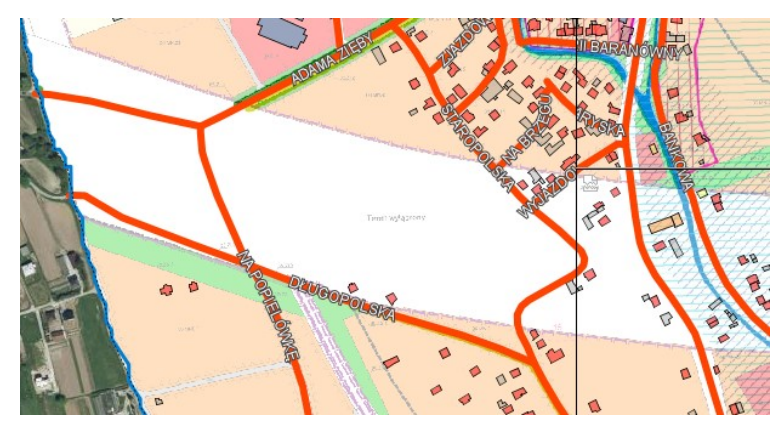

Fig. 2. The route of the beltway through the center of Zielonki. Source: http://portal.gison.pl/zielonki

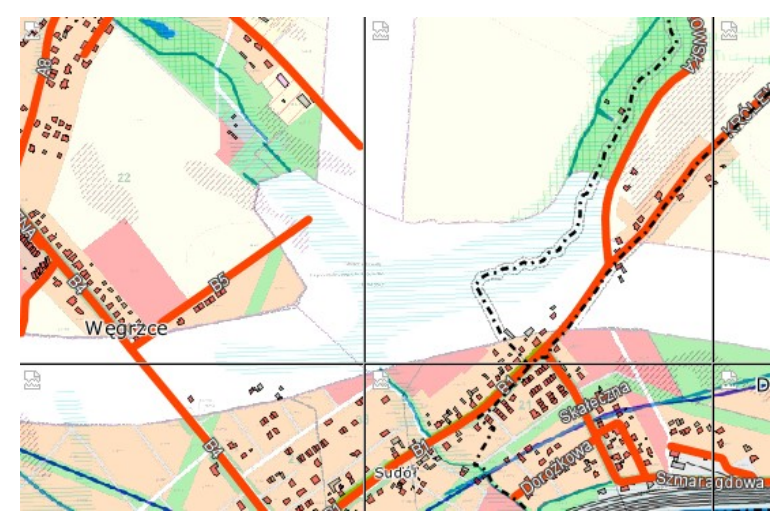

Fig. 3. The route of the beltway through Dziekanowice. Source: http://portal.gison.pl/zielonki

In the Dziekanowice region, the northern Krakow bypass runs through the marshlands. The planned route will exceed Sudoł Dominikanski stream. At the intersection of the northern beltway with the district road to Batowice, a node was designed. In this section, the route runs through partially built-up areas and agricultural areas. Then, the beltway runs along the railway line and through the areas of allotment gardens, up to the Nowohucki junction.

The major part of the route in option 1 runs through areas used as agricultural, green areas, communications, residential and other, such as valleys of rivers and streams, undeveloped fragments of protected areas, monuments and other reserves. The route of this variant runs through the Krakow Fortress Trail. In the place of the collision of the route with the buildings of the B-3 Battery and the choleric cemetery (written down to the register of monuments), it was proposed to lead the road in the tunnel. In the area of the discussed route, there are no Natura 2000 areas, nature reserves or ecological lands.

This variant makes use of the corridor, which has been leading to the northern beltway for about 50 years. The total length of the route according to variant 1 is approximately $11.5 \mathrm{~km}$. Due to the implementation of the planned investment, many engineering structures were designed, including 3 road junctions, 6 flyovers, 4 viaducts, 5 tunnels with a total length of approximately $3,160 \mathrm{~m}, 5$ culverts and service roads with a total length of nearly $19 \mathrm{~km}$.

\footnotetext{
* Corresponding author: preweda@agh.edu.pl
} 
The planned route of the beltway results in the necessity of demolition of 15 residential buildings, 22 farm buildings, 15 temporary greenhouses and 45 arbors on the grounds of allotment gardens

\subsection{Variant 3}

The route of the beltway according to this variant takes into account urban conditions - it goes beyond the dense housing development [1]. The ring road is moved north of the city limits of Krakow. From the Modlnica Junction the course of the route departs northwards, on the west side of Fort Tonie. The route then follows a high voltage line (Fig. 4).

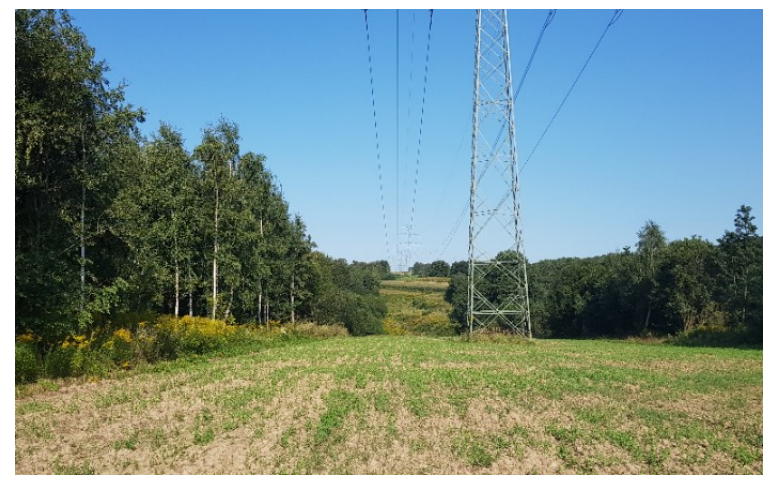

Fig. 4. Reserve along the high voltage line. Source: own study.

This area is a reserve used in the design of this variant. On the north-eastern side of Pękowice a road node from DW794 has been located. Behind the node, the beltway route runs through little built-up areas between Zielonki and Trojanowice, crossing among others the Bibiczanka stream. The further route of the beltway is still in the high-voltage line system.

Due to the buildings in the area of the intersection with DK7, a tunnel was designed to reduce the impact of the beltway on the surroundings. From the junction at DK7, the beltway runs further in the vicinity of the West-North line through the undeveloped areas between the Leśne Miodowski Forest and the towns of Boleń and Bosutów. Behind Bosutowo, a free space was used in order to descend southwards to the area of the railway line, along which the bypass was incorporated into the planned Nowohucki junction.

The total length of the route according to this variant is just over $14 \mathrm{~km}$. As in the case of variant 1, engineering structures were designed in the number of: 3 road junctions, 12 flyovers, 3 viaducts, 2 tunnels, 3 culverts, service roads and bridges connected with them.

The designed route of the beltway according to this variant requires the demolition of 5 residential buildings, 6 farm buildings, 42 arbors, 15 greenhouse greenhouses and 3 solid greenhouses [10].

\section{Elements of the impact of the planned bypass on the environment}

The planned area for the construction of the northern bypass of Krakow is mostly located in the Krakow
Upland, in the smaller part of the Miechów Upland. In terms of geology, it lies within the Śląsk -Krakowska Monocline, which borders on the east with Niecka Miechowska. Morphologically, this area is located within the Skłodu Upland of Małopolska. Based on [9], the development site is based on Jurassic, Cretaceous, Miocene settlements and quaternary settlements. Most of the soils from the analyzed area belong to the 2 nd and 3rd bonitation class, soils in class IV and lower occur in few, mainly on steep valleys and faults. Due to the high fertility of soils, agricultural production here is intense, especially in the vegetable and garden industry.

The vegetation of the Zielonki Commune [9] is characterized by a variety typical of the Krakow-Wielun Jurassic. Valuable natural communities of plants occur in a considerable distance - north of both variants of the planned bypass, in the valleys of Prądnik and Korzkiewka. There are small forest communities in the Pradnik valleys and its tributaries. In the undergrowth and on the outskirts of forests there are protected species of plants [11], however these habitats are outside the reach of the planned bypass.

The edges of all rivers and streams through which the planned bypass will run have a natural character and are usually overgrown with remnants of riparian forests (Fig $5)$.

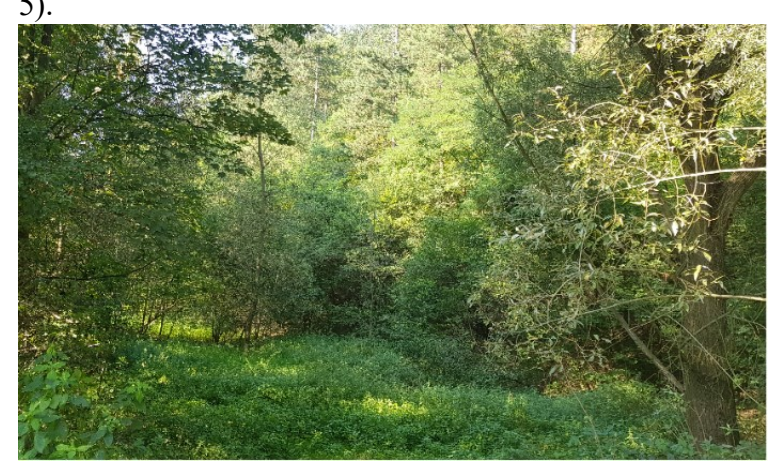

Fig. 5. Alluvial forest - Bibiczanka brook. Source: own study.

Endangered, rare and legally protected animals are found in the north-western part of the Zielonka Commune adjacent to the Ojców National Park.

\subsection{Choosing a variant more favorable for the environment}

In relation to the route of the road in option 1 , option 3 of the beltway leads through much less urbanized areas, these are mainly agricultural or wasteland areas. In contrast, the route according to the proposed variant 1 runs mainly on the old field reserve, in the vicinity of a much more settled area than in option 3 . On the basis of [10], the route of the planned bypass according to variant 3 passes utilitarian aquifers that serve to supply water to the inhabitants of the Zielonki commune. Therefore, work on the construction of the road and then its operation would require special protection of groundwater. Both options under consideration enter into the neighbouring areas of landscape parks: Krakow 
Landscape Park and Dłubnian Landscape Park $[13,14,15]$.

In terms of impact on the quality of life of residents, the impact on people is assessed as significant in the phase of road works. Especially in the case of variant 1, a nuisance is foreseen for the local community of the Zielonki commune through which the bypass is planned. They will be mainly related to the difficulty of access to individual properties, difficulty reaching service facilities, etc. In connection with the planned investment, demolition of residential and commercial buildings is expected. Despite the fact that some buildings have already been designated for demolition, there remain some buildings that will be exposed to adverse noise impacts. There will therefore be a decrease in the standard of living of people living or staying in the immediate vicinity of the road. The planned route, according to variant 3 , runs through areas much less invested and bypasses the housing development of the area of the commune of Zielonki. Due to the buildings in the area of the intersection with DK 7 and the location of the node on the hill, it was planned to build a tunnel, which in this area will offset the impact of the beltway on the surroundings. The bypass continues through undeveloped areas and along the railway line. In connection with the planned investment, demolition of buildings is also expected, but the impact on the quality of life of residents will not be as significant as in option 1.

Both variants of the planned bypass will have a significant impact on plants and animals. On the basis of [7] the destruction of the soil substrate within the area of the construction of the beltway, which is now the place of living of plants and animals, will completely eliminate the existing biocenoses there. In the immediate surroundings there may be a decrease in the amount of biomass, and thus, among other things, a reduction in the productivity of agricultural land. Because it is also planned to cut down trees and shrubs located along the route of the planned road, this will result in loss of biologically active areas for the natural environment, and thus the significance of the breeding area for birds will decrease and the places of refuge for mammals will decrease $[8,12]$. The estimated number of trees necessary for cutting out in the case of variant 1 is around 1,400 , and in the case of option 3 it is much larger. The construction of the beltway according to variant 3 would involve greater damages to natural habitats, including plants under strict protection. On the route of variant 3 , a greater number of protected animals and birds listed in the Annex to the so-called "Birds Directive" were also found.

Based on the natural inventory [2], it was found that there are no areas of the European Ecological Network Natura 2000 in the immediate vicinity as well as in the immediate scope of the planned project's impact. The closest area of Nature 2000 is PLH120069 Łąki Nowohuckie, about $3 \mathrm{~km}$ south of the Nowa Huta node and PLH120004 Dolina Prądnika - about $4 \mathrm{~km}$ north of the node in Modlnica. The main threat to the above area is air pollution. The calculations made in the report showed that the most favorable in terms of emissions to air is variant 1 of the bypass route, and after using the tunnel cover and screens, the operation of the beltway will not cause significant changes in pollution levels to the environment, outside the area immediately adjacent to the road. In connection with the above, the project located at a large distance from the Natura 2000 area under consideration will not affect the objects of its protection.

Taking the above into account, and additionally the possibility of changes in resources and contamination of usable aquifers, it was considered more beneficial for the environment for the planned route of the northern Krakow bypass according to variant 1 [10].

\subsection{The impact of the beltway at the operational stage}

Based on [10], potential adverse effects of the bypass on human health will be indirect, limited to a small group of residents living in the immediate surroundings of the planned road. In order to reduce the nuisance related to excessive noise emission, acoustic screens are planned.

Ecological corridors of national, regional and supralocal importance do not go through this area [5]. However, nowadays, in some regions, particularly notinvested, there are quite numerous animals, including protected invertebrates, amphibians, birds and mammals. Exploitation of the Cracow northern bypass, fumes, noise, road lighting and vehicle lights may cause the withdrawal of protected invertebrates and several species of birds from the neighbourhood. According to [2], invertebrates and birds found on the route of first variant bypass are quite commonly found throughout the country, and in the near and the immediate vicinity of the planned investment there are convenient habitats that enable their further existence. Animals that are reluctant to leave their area include amphibians and mammals [5]. For these animals, a road with six roadways, loaded with heavy traffic, is an impassable, often deadly barrier, preventing the passage to areas where they used to breed or feed. Currently, the main route of animal movement is the valleys of rivers and other watercourses as well as natural depressions. Designed overpasses and bridges over watercourses and culverts will at the same time allow passage for medium and small animals. This will reduce the negative impact of the planned bypass on the local fauna and reduce the incidence of road accidents involving animals

\subsection{Consultations and social conflicts related to the construction of the beltway}

The subject of public consultations was "the implementation of a variant concept of the northern Krakow bypass connecting the Modlnica two-level node on the western side with the S7 route located on the eastern side of the city". The report on the public consultations carried out is available in the Public Information Bulletin of the Marshal's Office of the Lesser Poland Voivodship. 
The purpose of the public consultations was to inform the public about the solutions and decisions taken, as well as to obtain information on the relation to particular variants. It made it possible to improve the quality of solutions and decisions taken. About proposals 2.5 thousand were collected in the form of proposals for changes, protests or support for individual options or the entire investment. For the most part, the proposals boiled down to protesting against the variant that will be directly adjacent to the applicant and supporting a more distant solution. The collected applications also concerned the request to discuss the problems of the planned solutions of the planned bypass and the issue of how the connections between the communes and the transport network of the city of Krakow will be solved. Part of the demands concerned the purchase price of real estate and compensation for the areas occupied by the planned bypass. It should be emphasized that variant 1 of the beltway, in line with Krakow's spatial development plans, at the turn of 2010 and 2011, was finally included in the spatial development plans of the Zielonki commune in agreement between the City Hall and the Commune Administrator, which detracts from the risk of possible protests against the construction of the beltway including variant.

\section{The impact of the planned bypass on the value of the properties}

Based on data from the Krakow Real Estate Market, the prices of construction land in the Zielonki commune, through which the northern bypass of Krakow is predominantly planned, are nearly the highest in the Krakow poviat (Fig. 6).

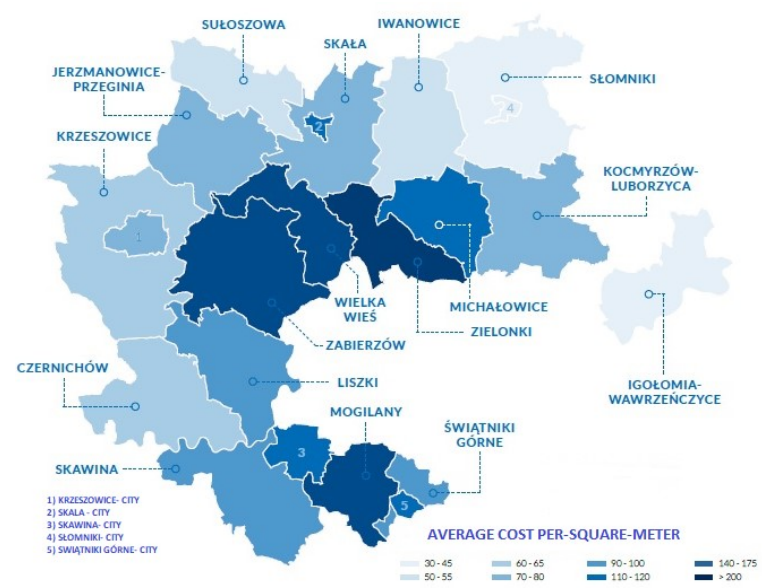

Fig. 6. Prices of construction land in the Krakow poviat. Source: Krakow Real Estate Market

The development of the Krakow poviat, and in particular the communes adjacent to Krakow, results from the competitive level of investment land prices relative to Cracow. The poviat areas attracted not only individual investors, but also developers [4]. In recent years, there has been an increase in the number of development investments, while individual investors still have a significant share in the total number of transactions - around $80 \%$ in issued building permits, which translates into over $70 \%$ of the residential area [2]. In 2017, the largest increase in prices was recorded in the commune of Zielonki (Fig. 7). Here, too, the largest increase in housing investment is observed.

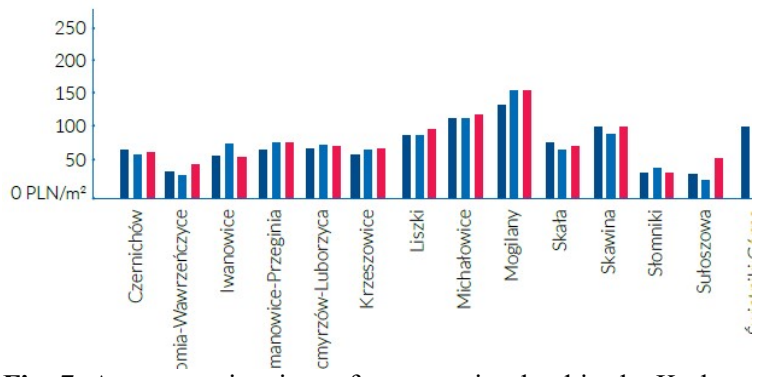

Fig. 7. Average unit prices of construction land in the Krakow poviat. Source: Krakow Real Estate Market

Similarly, the prices of agricultural lands are among the highest in the Krakow poviat [3] (Fig. 8).

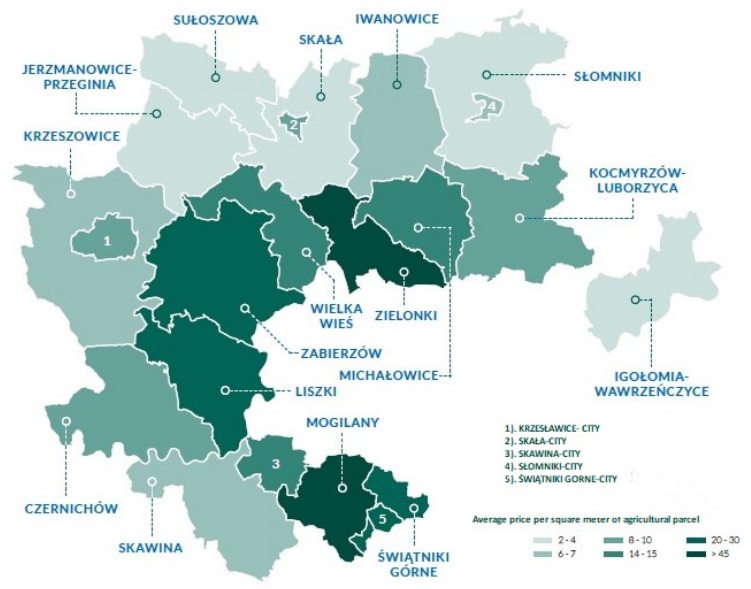

Fig. 8. Prices of agricultural lands in the Krakow poviat. Source: Krakow Real Estate Market

In 2017, the stagnation of land prices of the Krakow poviat was interrupted, lasting for several years. The agricultural real estate market has reacted to state policy. The effects of the Act of 14 April 2016 on suspending the sale of real estate of the Agricultural Property Resource of the State Treasury and on the amendment of some acts that limited the sale of agricultural real estate are visible. The decrease in the number of agricultural land transactions - resulting from legal restrictions translated into an increase in prices in this market sector. The number of large area agricultural land transactions has been decreasing, with the number of transactions of agricultural land remaining at a constant level of up to 30. This state of affairs justifies the increase in average agricultural real estate prices, particularly visible in the neighbouring municipalities of Cracov (Fig. 9). It can be concluded that the residential real estate market is in its heyday. 


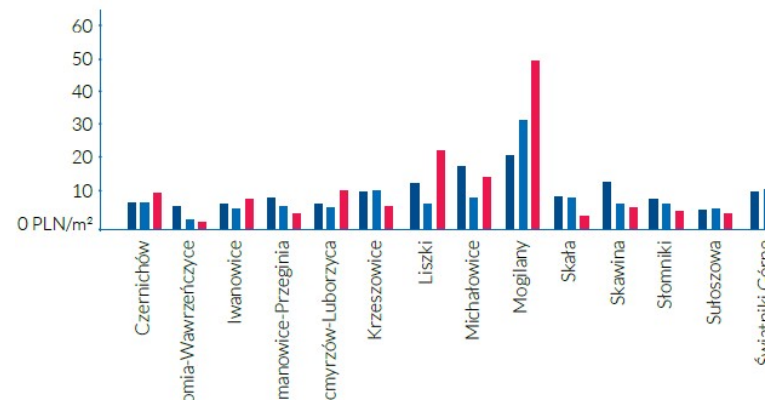

Fig. 9. Average unit prices of agricultural land in the Krakow poviat. Source: Krakow Real Estate Market

Analyzing the prices of real estates in the immediate vicinity of the Wrocław bypass of Wrocław [4], it was noticed that the prices of real estate in its immediate vicinity within two years of its opening decreased by about $25 \%$. In the area of the beltway nodes or in the towns surrounding the city, prices remain at the same level. Mechanists expect a similar mechanism in the municipalities located north of Krakow. In the immediate vicinity of the beltway, the attractiveness of plots will fall, thus they will lose their value. In the area of the bypass nodes (Fig. 10), due to the infrastructure associated with it, prices may even rise slightly [17].

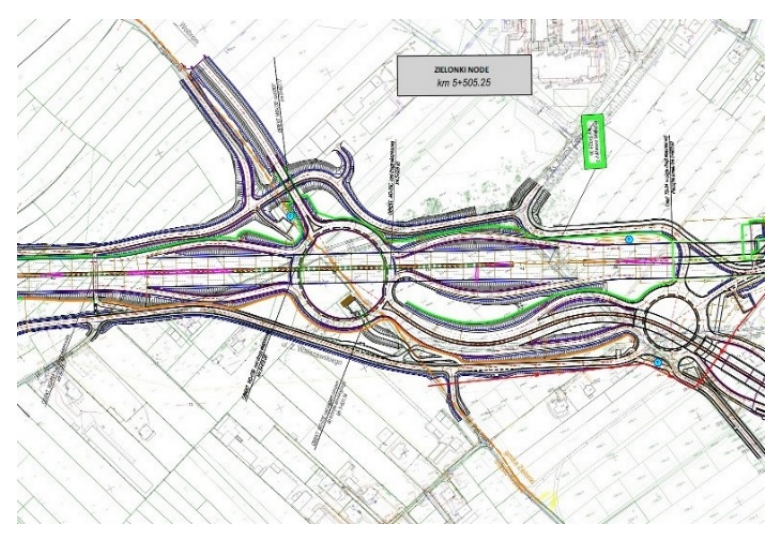

Fig. 10. Zielonka node. Source GDDKiA

In the areas where the route will lead in tunnels, prices will remain at a similar level as currently. The increase in the number of development investments in the communes, the increase in prices on the investment market and the constant number of construction land transactions in the poviat prove that prices in this market sector are slowly reaching the borderline. However, the value of plots further from the planned route will certainly increase slightly [6]. The dynamics of this growth may take place already during the implementation of the investment, and certainly after its completion. Analysis of real estate transactions with built-in single-family houses inn Cracov and its area indicates that after four years of growth from 2012 to 2016, in 2017 the trend has changed. It is noted that the prices of real estates built-up with single-family houses are stabilizing (Fig. 11).

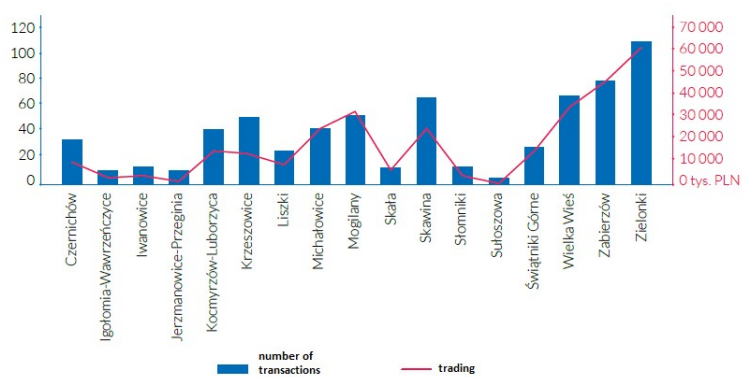

Fig. 11. Number of transactions and turnover of houses in the districts of the Krakow poviat in 2017.

In 2017, as in previous years, by far the largest number of single-family house transactions was noted in the municipalities of Zielonki and Zabierzów and further in Wielka Wieś and Skawina. The construction of the northern bypass of Cracov, and thus smaller traffic jams during commuting to work in Krakow, will certainly translate into even greater interest in single-family houses in the northern part of Krakow's communes.

\section{Reference to the Lviv Beltway}

The State Road Motor Agency of Ukraine, in August 2017, agreed to develop a design documentation for the construction of the northern bypass of Lviv. The experience from the construction of the Krakow bypass can be very useful for the implementation of this project. Motorway M10 (ukr. Автомагістраль M10) - is designed in Ukraine along the European route E40. The motorway will allow access from Korczowa (in Poland) to Lviv and will form the northern part of its beltway. The first decree regarding the construction of the motorway on the route Lviv - Krakowiec (border crossing) was issued by the President of Ukraine in 1998. According to the concession agreement, the construction was to last 5 years. However, due to the lack of financing, the project did not proceed [18]. In 2010, the Polish Deputy Prime Minister Waldemar Pawlak met with the Deputy Prime Minister of Ukraine, Borys Kolesnikov, where the topics of the development of the border crossing Korczowa-Krakowiec and the construction of the road Lviv- Kraków were discussed. During the meeting, both prime ministers took part in the ceremonial laying of the cornerstone for the construction of the motorway. This act inaugurated the commencement of the construction of the M10 motorway [18]. In January 2011, on the area of the future motorway, geological and geodetic tests were carried out, fortification of marshy plots of the route and transfer of underground installations.

In March 2011 the head of the Lviv Regional State Administration, Mykhailo Cymbaluk, informed that Lviv did not receive any funds for the construction of the motorway until that time. In the same month, the deputy chairman of the Lviv Regional State Administration for the preparations of Euro 2012, Volodymyr Hubycki, admitted that the construction of the Krakov-Lviv motorway was postponed indefinitely, probably to the planned implementation of the Olympics by Ukraine in 
2022. The reason for the problems was the lack of financial resources - the first stage of road construction would cost 1.5 billion hryvnia (4.6 milion EUR). However, these funds were intended for renovation and reconstruction of existing roads [19].

The road begins at the Polish-Ukrainian border crossing in Krakowiec, being an extension of the Polish A4 motorway (continuation of the cross-border Europewide Berlin - Dresden - Wrocław - Katowice - Krakow - Rzeszów - Lviv - Kiev route), and ending near the village of Griada in the suburb of Lviv (Fig. 12).

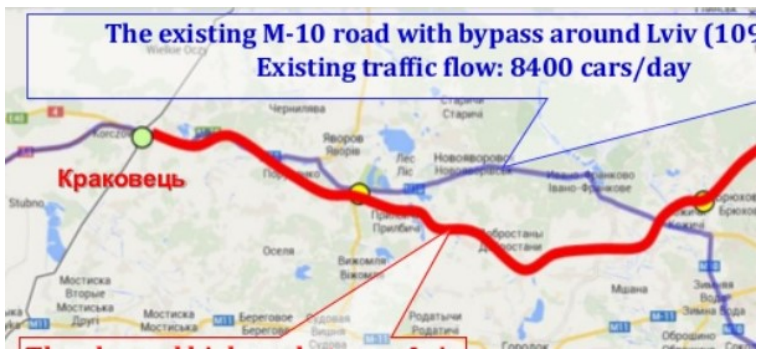

Fig. 12. Road Krakowiec - Lviv [21]

The planned length of the road is $84 \mathrm{~km}$. The road is to be built in accordance with the highest standards , avoiding cities, residential areas, with a designed speed around $130 \mathrm{~km} / \mathrm{h}$. In 2007, as part of the organization team of Euro 2012, the Department of Urban Planning, Architecture and Spatial Development of the Lviv Regional State Administration planned to extend the Krakow-Lviv motorway to Równe. In 2008, it was announced that the motorway would lead from Krakow, through Lviv, to the town of Brody. In the case of this direction, the M10 would have $162 \mathrm{~km}$. At the end of May 2015, the Ukrainian side made another attempt to launch the motorway project. Ukrainian State Road Agency Ukravtodor has announced a competition for the construction of a licensed section of the Lviv- Krakow highway. Two companies submitted bids for the construction of the first phase. Ukravtodor, however, posted information on its official website about the cancellation of this tender, motivating the decision that: "none of the companies is able to provide financial resources for the construction of the object or concession, own resources, or borrowed, in accordance with the requirements set out in the tender concession". M10 is still suspended [18].

\section{Conclusions}

The planned project, which is the construction of the northern bypass of Krakow, is necessary for the proper functioning of the transport system connecting Kraków with the areas located north of the city. It will provide a high-quality car connection on the east,west and north directions and relieve the Krakow bypass from transit traffic, which in the future will improve the capacity of the Cracov road system. It is also estimated that the northern beltway will significantly improve the safety of users and the comfort of living for the residents of the city of Krakow and will allow avoiding damage to the infrastructure caused by strong vibrations caused mainly by heavy cars. It will also improve communication conditions in the commune of Zielonki and facilitate the connection of northern communes with Krakow.

After the construction of the planned investment, the east-west traffic will be separated into the northern and southern part of the Cracov bypass, relieving the southern beltway of Krakow, overloaded with vehicle traffic. In addition, the possibility of using the northern and southern bypass of Krakow will allow, in the conditions of possible blocking of traffic, to ensure continuity of journeys in the direction of RzeszówKatowice. The ring road of Krakow will connect all outlets of national roads on the northern side of the city (A4, DK 79, DK 94, S7), which will allow you to move also from the west towards the north (Kielce, Warsaw), the west (Katowice, Wrocław), the east (Tarnów, Rzeszów) without having to cross a crowded city. It will take over all transit traffic, as well as part of the urban traffic currently passing through the northern part of the city via DK 79. According to forecasts, in the new section, as early as in 2025 , traffic will exceed 30.000 vehicles per day.

On the basis of the Report on the impact of the planned investment on the environment, it can be concluded that the planned investment implemented according to variant 1 will not cause significant changes in the natural environment. According to experts, the construction of the beltway will be of great importance in the context of activities that have been undertaken in Krakow for years to reduce smog and dust suspended from the city center.

The construction of the northern Krakow bypass will have a positive impact on the real estate market in this part of the Krakow poviat. It is expected that the decline in the value of real estate will be recorded only in the immediate vicinity of the beltway. Due to the more favorable travel time to Krakow, the number of transactions, both land and builded land, and, above all, single-family homes, will surely increase.

The reference to the construction of the M10 motorway in Ukraine, which is to constitute the Lviv Beltway at the same time, is quite difficult at this stage. Certainly experience related to the construction of the northern Krakow bypass, which has been planned for several decades, can be helpful in the logistics and procedural field.

\section{Acknowledgement}

Publication supported by the Polish Ministry of Science and Higher Education as a part of the program of activities disseminating science from the project „Organization of the First International Science Conference - Ecological and Environmental Engineering”, 26-29 June 2018, Kraków.

This work was carried out within the statutory studies of the AGH University of Science and Technology, Faculty 
of Mining Surveying and Environmental Engineering, Department of Geomatics No. 11.11.150.006.

\section{References}

1. Butryn K., Preweda E. Analysis of the impact of quantitative and qualitative price-setting attributes on a market of real estate intended for the purpose of the transformer stations on the example of Krakow. The 10th International Conference Environmental Engineering : selected papers : April 27-28, 2017, Vilnius, Lithuania (2017)

2. Jasińska E. Land use efficiency on example of the transformation of rural properties. The 10th International Conference Environmental Engineering : selected papers : April 27-28, 2017, Vilnius, Lithuania, (2017)

3. Jasińska, E., Preweda, E. Infrastruktura i Ekologia Terenów Wiejskich. Nr 01/III, p. 31-40. (2012)

4. Jasińska, E. Real Estate Due Diligence On the Example of the Polish Market. 14th SGEM GeoConference on Informatics, Geoinformatics and Remote Sensing 2. SGEM2014 Conference Proceedings, June 19-25, 2014, Vol. 2, Bulgaria (2014)

5. Korytarze ekologiczne w Małopolsce, Instytut Nauk o Środowisku UJ, Instytut Ochrony Przyrody PAN, Kraków (2005)

6. Mika M. Acta Sci.Pol. Form. Cir. 16.1: 3-14. (2017)

7. Podręcznik dobrych praktyk wykonywania opracowań środowiskowych dla dróg krajowych, EKKOM, Kraków (2008)
8. Program ochrony środowiska Gminy Zielonki 20042014.

9. Raport o stanie środowiska w województwie małopolskim w 2013r, WIOŚ Kraków (2014)

10. Raport oddziaływania na środowisko dla budowy Północnej Obwodnicy Miasta Krakowa (2012)

11. Rozporządzenie Ministra Środowiska z dnia 9 października 2014 roku w sprawie ochrony gatunkowej roślin.

12. Rozporządzeniu Ministra Środowiska $\mathrm{z}$ dnia 6 października 2014 roku w sprawie ochrony gatunkowej zwierząt.

13. Studium uwarunkowań i kierunków zagospodarowania przestrzennego gminy Wielka Wieś.

14. Studium uwarunkowań i kierunków zagospodarowania przestrzennego gminy Zielonki.

15. Studium uwarunkowań i kierunków zagospodarowania przestrzennego gminy Michałowice.

16. Ustawa $\mathrm{z}$ dnia 3 października 2008 r. o udostępnianiu informacji o środowisku i jego ochronie, udziale społeczeństwa w ochronie środowiska oraz o ocenach oddziaływania na środowisko (Dz. U. $\mathrm{Nr}$ 199, poz. 1227 z pózn. zm.)

17. Wójcik-Leń J., Sobolewska-Mikulska K., Sajnóg N., Leń P. Land Use Policy 78, 36-45. (2018)

18. https://zaxid.net/news

19. http://www.mpit.gov.pl/

20. https://zielonki.pl

21. https://mtu.gov.ua/ 